\title{
TOWARD A DECIPHERMENT AND LINGUISTIC RECONSTRUCTION OF THE 1101 A.D. KITAN EULOGY FOR EMPRESS XUANYI, WITH NOTES ON MONGOLIC COGNATES: LINES $1-6$
}

\author{
ANDREW SHIMUNEK ${ }^{*}$ \\ Woosong University \\ 196-5 Jayang-dong, Dong-gu, Daejeon 300-831, Republic of Korea \\ e-mail: ashimune@umail.iu.edu
}

\begin{abstract}
This paper is the first in what aims to be a series of papers toward a new decipherment and linguistic reconstruction of the Kitan Assembled Script Eulogy for Empress Xuanyi of 1101 A.D. In my treatment of this inscription, I have attempted to juxtapose the Kitan text and its very roughly corresponding Chinese text as much as possible, to allow for greater accuracy in decipherment and reconstruction. This methodology has allowed me to identify several words with previously unnoticed Mongolic cognates.
\end{abstract}

Key words: Middle Kitan (ca. 907-1125), Mongolic, historical linguistics, script decipherment, philology, Xuanyi Inscription.

\section{Introduction}

The most recent studies of the Xuanyi huanghou aice 宣懿皇后哀冊 inscription include Chinggeltei et al. (1985), Chinggeltei (2002), Kane (2009), and Batu (2012). The most detailed and careful study of the text by far is Kane (2009). My paper would not be possible without these previous studies, or without Oyuunch's groundbreaking exploratory study of Kitan grammar (2007) and the important details and proposals offered by Oyuunch - Janhunen (2010).

* I thank Valerie Hansen for inviting me to Daniel Kane's Kitan Crashcourse at Yale University, which gave me access to several resources I have used in this paper. I am grateful to Daniel Kane for our lively and enlightening conversations at Yale, which have made this paper much better than it would have been. I also wish to thank György Kara for reading a draft of my paper and for providing helpful comments; Daniel Kane, Kurban Niyaz, Oyuunch (Wu Yingzhe), Lance Pursey, and Jonathan Dugdale for providing books, scans, photos, and other resources which I have used in preparing this paper; Andrew West for his freeware Kitan font which I have employed in this paper; and William Merrill for his help with Kitan input for Mac. Any errors in this paper are entirely my own. 


\section{The Text}

Although the Kitan Xuanyi inscription is accompanied by a corresponding Chinese inscription, the two texts differ significantly from each other. There are many parallels to be identified, and many correspondences, but significant portions of these texts differ from each other with regard to specific details. Unlike the Langjun xingji 郎君 行記 inscription, which consists of a Kitan text and its Chinese translation, the Xuanyi Inscription consists of two separate, independently written texts, by separate calligraphers - the Kitan text was calligraphed by Yelü Gu (i.e. *Yarud ${ }^{*} \mathrm{Gu}$ 开有友火 乞友久 in Kitan), and the Chinese text was calligraphed by the Liao Chinese official Zhang Lin 張琳. ${ }^{1}$ It is thus not always possible to juxtapose the Kitan text with corresponding sections in the Chinese text. However, at least for the first six or so lines of the inscription, the Kitan and Chinese texts generally correspond to each other closely. Juxtaposing clauses and sentences from the Kitan text with their corresponding lines in the Chinese text has allowed me to uncover some previously unidentified Mongolic cognates.

For rubbings of the original text, see Chinggeltei et al. (1985), Chinggeltei (2002), Liu et al. (2009), and Liu (2014). See Liu (1999), Chinggeltei (2002), Kara (2005), Kane (2009), and Oyuunch-Janhunen (2010) for the historical background of the text. Note that ' $\mathrm{K}$ ' denotes lines in the Middle Kitan text, while ' $\mathrm{C}$ ' denotes the corresponding lines in the Chinese text. In my treatment of the Kitan lines, I first present a printed version of the original line in Kitan Assembled Script, followed by a philological transcription of the grapheme blocks, then a morphophonological reconstruction of the Kitan words, followed by an interlinear morpheme-by-morpheme gloss, and an English translation of the text, when possible. Following Kane (2009), Kitan data are given horizontally.

My analyses of the text are organised as follows:

1. sentence in Kitan Assembled Script

2. orthographic transcription

3. morphological and phonological transcription

4. interlinear morpheme gloss

5. translation (when relevant)

[K1]

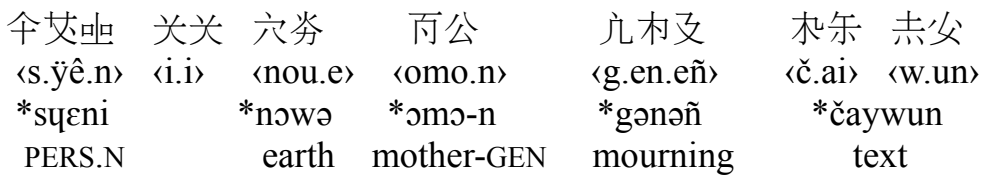

${ }^{1}$ See Kane's (2009, p. 223) translation of the Chinese text of the Xuanyi inscription. 


\section{[C1]}

\section{宣懿皇后哀冊}

These lines correspond closely. Middle Kitan *nowə 穴炎 〈nou.e〉 'earth' is probably cognate to Middle Mongol noqo'an 'green'. The grapheme 穴 is usually read «neu〉 based on its Old Mandarin transcription in the Liao Shi 遼史, but this transcription could just as easily transcribe a foreign syllable like «nou〉. Middle Kitan *oms 丙 〈omo〉 'mother' is cognate to Middle Mongol eme 'woman'. 'Middle Kitan *nowə *oms 穴炎而, literally 'earth mother', is a respectful term for 'empress', as shown by Kane (2009). The *-n is a genitive-attributive suffix cognate to Middle Mongol -un $\sim-\ddot{u} n \sim-y i n \sim-u \sim-\ddot{u}$ 'genitive case suffix'.

As pointed out by previous scholarship, the word 九木及 'mourning, grieving (哀)', which I reconstruct as *gənəñ, superficially resembles Written Mongol runi'to be sad, melancholy', but the vocalism poses a problem. The Middle Kitan form is probably a deverbal form based on a verbal root *gən- 九村 'to mourn, grieve' +

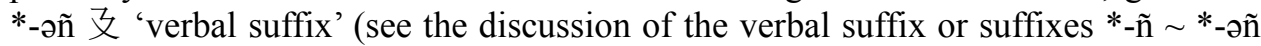
in the commentary on line K5 below).

As shown by Kane, the grapheme 余 in Chinggeltei's reading of the text should be revised to 尔 (Kane 2009, p. 214, note 57), which I read as 〈ai〉, rendering *čaywun 本尔圭父 'text', from an Old Mandarin reading of 冊文 'id'.

\section{[K2-K3]}

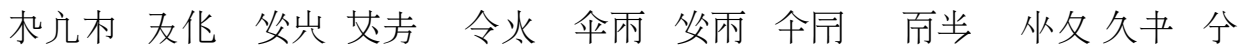
〈č.g.en〉〈uw.ur〉〈ng.ü〉〈ÿê.ên〉〈t.ung〉〈ts.in〉〈ng.in〉〈s.ing〉〈čau.ung〉〈l.u〉〈da.ai〉〈pu〉

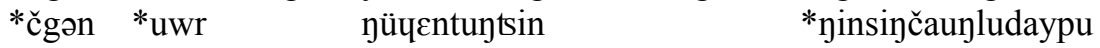
left division ceremonial.receptionist grand.master.of.imperial.entertainments

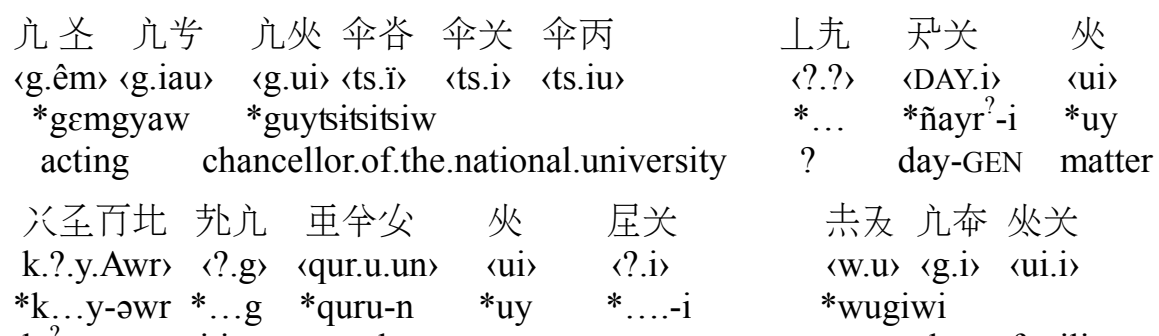
do ${ }^{\text {-CVB }}$ writing control-GEN matter manage-CVB commandant.of.military.cavalry

出及几而车灭九㕛取企平个网为本 〈pu.uw.ku〉〈y.ar.uw.ud〉〈g.u $\left.{ }^{\mathrm{w}} . \mathrm{u}\right\rangle\langle\mathrm{k} . \mathrm{em}\rangle\langle$ 〈o.or〉 〈COMPOSE.a.ar〉 *puwku *yarud *gu *kəm *... -r *...a-r official PERS.N PERS.N edict receive-PST ${ }^{\hat{\alpha}}$ compose-PST $^{\hat{O}}$

\footnotetext{
${ }^{2}$ On the reading of the grapheme 百 as ‘omo〉, see Tang (2011, p. 197).
} 
'Composed, according to imperial edict, by the official Yelü Gu, Ceremonial Receptionist of the Left Division, Grand Master of Imperial Entertainments with Silver Seal and Blue Ribbon, Acting Chancellor of the National University, Keeper of the Daily Agenda of the Emperor, Director of the Hanlin Academy, Commandant of Military Cavalry."3

The phrase 机え村友化 denotes 'Left Division', an administrative division within the Kitan government; Middle Kitan *čgən 九九木 'left (side)' is cognate to Middle Mongol je' 'ün and Preclassical Written Mongol jegün 'left (side)'. ' The word *uwr

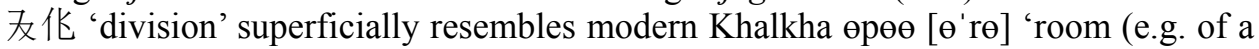
building)' and modern Written Mongol örüge 'room' both semantically and phonologically, but a connection, if any, is difficult to ascertain at present; this modern Written Mongol word is not attested in Middle Mongol or the peripheral Mongolic daughter languages, and a Proto-Mongolic word for 'room' is not reconstructable. The traditional Serbi-Mongolic dwelling, the yurt (i.e. Middle Mongol ger and Middle Kitan *gor 灲众 go. $\left.\left.{ }^{\mathrm{e}} \mathrm{r}\right\rangle\right)$, does not have rooms.

The phrase *čgon *uwr 机九村 友化 'Left Division' is followed by Kitan transcriptions of Liao Chinese titles: as shown by Kane (2009, p. 215, note 59), 众岀 艾去令火伞雨 父雨羊闰 transcribes the Liao Chinese phonological values of

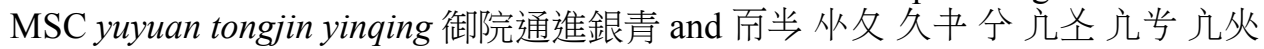
伞吕伞关舍 transcribes chonglu dafu jianjiao guozi jijiu 崇祿大夫檢校國子祭 酒. According to Hucker, yuyan tongjin 御院通進 denotes “Ceremonial Receptionist... responsible for receiving memorials, tribute gifts, etc., in audience” (Hucker 1985, \#8215). The title yinqing chonglu dafu 銀青崇祿大夫 is not discussed by Hucker, but he notes two similar titles, yinqing ronglu dafu 銀青榮祿大夫 'Grand Master for Glorious Happiness with Silver Seal and Blue Ribbon’ (\#7980) and yinqing guanglu dafu 銀青光祿大夫 'Grand Master of Imperial Entertainments with Silver Seal and Blue Ribbon' (\#7981). Kane (2009, p. 215, note 59) translates the Liao Chinese title 銀青崇祿大夫 as 'Grand Master for Exalted Happiness with Silver Seal and Blue Ribbon'. According to Hucker, chonglu si 崇祿寺 (\#1666) is the Liao Chinese equivalent to guanglu si 光祿寺 'Court of Imperial Entertainments' (\#3348); thus, the Liao Chinese title 銀青崇祿大夫 should be understood as 'Grand Master of Imperial Entertainments with Silver Seal and Blue Ribbon', i.e. a title equivalent to 銀青光祿大夫 'Grand Master of Imperial Entertainments with Silver Seal and Blue Ribbon' in Sui-Sung terminology. The phrase jianjiao 檢校 denotes 'acting' (\#804) and guozi jijiu 國子祭酒 is 'Chancellor of the National University' (\#3540).

The word form 上旮 also appears in the Yelü Jue muzhiming 耶律玦墓誌銘 inscription (YJue 29:38, 25:9, 4:53) and in the Xiao Hudujin muzhiming 蕭胡暏革墓 誌銘 inscription (XHu 13:2), but the precise meaning is not clear. In XHu (13:2), 上无 modifies 'daily agenda (日事)' in the same phrase as here in the Xuanyi inscription,

\footnotetext{
${ }^{3}$ This is my revision of Kane's (2009) English translation.

${ }^{4}$ The meaning 'east' or 'eastern' in reflexes of this Middle Mongol word in Khalkha and certain other Mongolic languages is a very recent semantic innovation. In Middle Mongol, this word meant only 'left (side)' (Shimunek 2017, p. 345).
} 
i.e. 上旮天头众 $(X H u$ 13:2-4), although modified with *-də 矢 〈.de〉 'dative-locative suffix'.

As shown by Kane (2009) and Oyuunch (2012), Kitan 天炎 众 denotes 日事 'daily agenda', literally 'matters of the day'. The word 天炎 is composed of 天 'day' with *-i 兴 'genitive case suffix'. Note another occurrence of the noun phrase 天炎 'of the day' in the Xiao Huilian muzhiming 蕭回璉墓誌銘:

$\begin{array}{cccc}\text { 乇 } & \text { 尺关 } & \text { 杏 } & \text { 兆 } \\ \text { 〈mas〉 } & \text { ¿ñayr?.i〉 } & \text { 〈uñ } & \text { 〈po〉 } \\ \text { *mas } & \text { *ñayr-i } & \text { *uñ } & \text { *po } \\ \text { one } & \text { day-GEN } & \text { ox } & \text { time }\end{array}$

'at the Ox Hour of the first day, ...' (XHui 28:21-24).

The Kitan word *k...y-əwr 八圣开比 appears to be a verb with *-Awr 北 〈.Awr〉 'converb suffix'. and the other occurrences of this grapheme which I have been able to identify are not particularly informative (e.g. $G u$ 11:17, $X u$ 27:15, 28:13, 42:40, 42:42, 24:34, 41:14; YXiang 37:37, 17:4; XDi 29:3; XHu 26:10; YJue 11:37; Zhong 14:48, 10:31). As a productive hypothesis, this *k...y-əwr might be a verbal construction similar to Written Mongol kiged, composed of ki- 'do' + -GAd 'perfective converb suffix', i.e. 'do and then...' Written Mongol kiged usually functions as a conjunction, e.g. qayan kiged qatun 'the king and the queen' (Poppe 1954, p. 122, §432). Given the sentential context, Kitan *k...y-əwr probably has a similar function. The precise semantic value of the converb suffix *-Awr t地 has yet to be elucidated, but for the time being we may entertain the possibility that it is a perfective converb suffix. Note the following example of this suffix:

\begin{tabular}{|c|c|c|c|c|c|c|}
\hline $\begin{array}{l}\text { 及炎 } \\
\text { 〈eñ.e〉 } \\
\text { *ə̃̃̃ } \\
\text { now }\end{array}$ & $\begin{array}{l}\text { 百余从众 } \\
\text { 〈omo.qu.ui〉 } \\
\text { *omoqu-y } \\
\text { return-CVB }\end{array}$ & $\begin{array}{l}\text { 父众化午比 } \\
\text { k.ui.ir.s.Awr〉 } \\
\text { *kuyr-səwr } \\
\text { return-CVB }\end{array}$ & $\begin{array}{l}\text { 及由 } \\
\langle\mathrm{eñ.?〉} \\
\text { *əñ... } \\
\text { now(?) }\end{array}$ & $\begin{array}{l}\text { 圣尚 } \\
\text { 留ur.en〉 } \\
\text { *jur-ən } \\
\text { painting-PL }\end{array}$ & $\begin{array}{l}\text { 老方 } \\
\text { 〈šên } \\
\text { *šen } \\
\text { new }\end{array}$ & $\begin{array}{l}\text { 北及比 } \\
\text { 〈p.o.ju.Awr〉 } \\
\text { *poju-awr } \\
\text { become-CVB }\end{array}$ \\
\hline $\begin{array}{l}\text { 気 } \\
\text { ang> } \\
\text { ay } \\
\text { rridor }\end{array}$ & $\begin{array}{c}\text { 曲九 } \\
\text { 〈go.č〉 } \\
\text { *goč } \\
\text { r } \quad \text { ?-CVB }\end{array}$ & $\begin{array}{c}\text { 几火炎 } \\
\text { «ku.ud.uw.ui> } \\
\text { *kuduw-i } \\
\text { ?-CVB }\end{array}$ & $\begin{array}{c}\text { 仍尚炎 } \\
\text { <?.en.er> } \\
\text { *...ən-ər } \\
\text { ?-PST }\end{array}$ & & & \\
\hline
\end{tabular}

'Now, he returned, and ... the paintings had become new, and the corridors were ... and ...' (Lang 3:9-4:6; Shimunek 2014, pp. 103-104).

The phrase 扎几 旡㐁父 众 㞋头 denotes 'Director of the Hanlin Academy' (Kane 2009). This title is attested in the same form in the Daozong huangdi aice 道宗皇帝 哀冊 inscription (Dao 2:19-22), which Liu et al. (2009, p. 466) gloss as 'Director of the Hanlin Academy (總知翰林院事)'. It is informative to note that the title 知事 'administrator' or 'administrative clerk' in Chinese corresponds to a verb phrase in Kitan, usually a subordinate clause marked with a converb suffix or a finite clause

\footnotetext{
${ }^{5}$ On the phonological value of the grapheme 比, see Shimunek (2017, pp. 423, 428).
} 
ending in a past tense suffix. Titles formed from the verb 㞋 'to manage' are attested throughout the Kitan Assembled Script inscriptions, but the phonological value of this verbal root is, for the time being, enigmatic. Note other instances of titles based on the verb root*...- 㞋 'manage':

\begin{tabular}{|c|c|}
\hline $\begin{array}{l}\text { 众 } \\
\text { 〈ui }\end{array}$ & $\begin{array}{l}\text { 屋众 } \\
\text { 〈?.er〉 }\end{array}$ \\
\hline & $\begin{array}{l}* \ldots \text { *.ər } \\
\text { manage-PST }\end{array}$ \\
\hline
\end{tabular}

'Administrator (知事)' (Jiao 13:26-27).

\begin{tabular}{|c|c|c|}
\hline & 机去父 & 众 \\
\hline *tan & *čəw-un & * uv \\
\hline
\end{tabular}

Tan prefecture-GEN matter manage-PST ${ }^{\widehat{\lambda}}$

'Administrator of Tan Prefecture (檀州之知事)' (Song 10:32-35; Liu et al. 2009, pp. 270, 468).

Kitan *wugiwi 去友 几夻夾谷 is a transcription of the Liao Chinese pronunciation of the title wuji wei 武騎尉, translated by Hucker as 'Commandant of Military Cavalry' (\#7741).

The word *puwku 出友几 〈pu.uw.ku〉 denotes 'official (臣)' (Kane 2009, p. 215, note 59), and is a compound composed of *puw 出友 〈pu.uw〉, a transcription of Old Mandarin 僕 'servant' (cf. Kane 2009, p. 115, §3.179), and the inherited SerbiMongolic word * $\mathrm{ku}$ 几 $\langle\mathrm{ku}\rangle$ 'person', cognate to attested Middle Mongol kü'ün

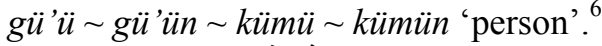

The word 双企 〈k.em〉 is cognate to Middle Mongol kem 'limit' (SHM §199). ${ }^{7}$ The word 雨乏 $<$ ?.or has not been phonologically deciphered, although it has been semantically deciphered as a Kitan verb equivalent to Chinese 奉 'receive from a superior or to submit to a superior' (Kane 2009). The suffix 个 个 <.or〉 denotes the masculine past tense, and suggests that the verbal root 再 ends in the vowel $o$. I thus reconstruct *...o- 雨 $\langle ? 0$.$\rangle 'to submit to a superior or to receive from a superior (奉)'. Here$ the phrase 取企雨全 literally means 'received an edict', but the general meaning is 'according to imperial edict'.

The word 网为虫 〈?.a.ar〉 is a masculine past tense verbal noun based on the verbal root $\times$ ' compose'. Although this root has not been phonologically deciphered, the fact that there is an 为本 (.a.ar〉 concatenated to the root suggests that $\mathrm{m}$ includes a [-ATR] vowel, possibly *[a]. In the Yelü Pusuli muzhi beiming 耶律蒲速里墓誌碑 銘 inscription, this verb appears with the [-ATR] causative-passive suffix *-ва- 来 in

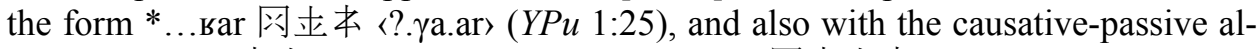

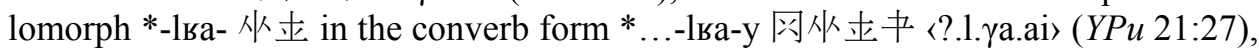
which might also suggest that the root of this verb contains an *[a] vowel. Note also

\footnotetext{
${ }^{6}$ See Shimunek (2017, p. 349) for the etymology of this Serbi-Mongolic word.

${ }^{7}$ Shimunek (2017, p. 347). See also Shimunek (2011, p. 104).
} 
*...a-r (?) or *...-ar (?) 网为丸〈?.a.ar〉 (XHu 1:26; YJue 1:29) and the feminine past tense form *...a-n (?) or *...-an (?) 网为出 ?.a.an〉 (XHu 22:16).

Since the Kitan and the Chinese texts were written by different people and for different audiences, the corresponding Chinese passage is quite different in content from the Kitan text, consisting of the epithets and titles of the Chinese official who calligraphed the Chinese text. See Kane (2009, p. 223) for a translation of this line of the Chinese text. Since it is not relevant for the Kitan text, I will not give the Chinese text or a translation here.

\section{[K4]}

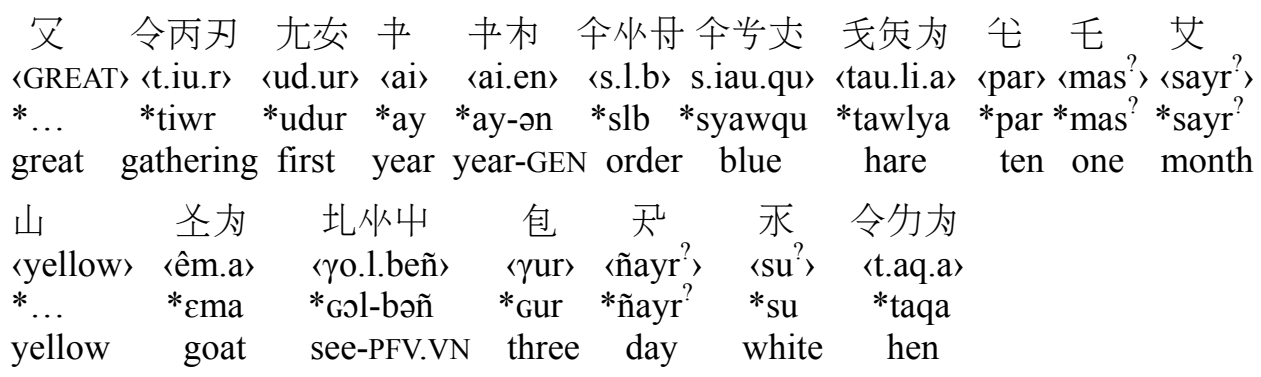

'[It was in] the first year of the Great Gathering reign period, the order of the year was Blue Hare, the eleventh month, Yellow Goat, the third day, White Chicken.'

\section{[C3]}

\section{維大康元㕿歲次乙外十一月己未朔三日辛西}

'It was in the first year of the Dakang reign period, the order of the year was yimao (i.e. 1075 A.D.), the eleventh month, jiwei, the third day of the new month, xinyou. ${ }^{8}$

The Kitan and Chinese lines above closely correspond to each other. The Kitan line contains a number of Mongolic cognates, including *tiw-r 令刃 'gathering,' a deverbal noun composed of *tiw- 令丙 'gather' with *-r 刃 'deverbal noun suffix'. 10 The word *udur 九交 'first' is possibly a semantic extension of the homophonous word *udur 九化 'east', which is cognate to Middle Mongol üdür 'day, daytime'.11 Kitan *ay † 'year' is a well-known word of high frequency. The word 羊夾亓,

\footnotetext{
${ }^{8}$ My translation of this line of the Chinese text is a revision of Kane (2009, p. 223).

${ }^{9}$ This grapheme compound is read 令商刃 by Chinggeltei (2002, p. 119), but rubbings of the original text clearly show 令丙刃.

${ }^{10}$ See Shimunek $(2014$, pp. 107, 115) and Shimunek (2017, p. 373) for Mongolic cognates of this Kitan word.

${ }^{11}$ See Shimunek (2017, pp. 376-377) for the etymology of Middle Kitan *udur 'east' and Middle Mongol üdür 'day, daytime'.
} 
which I reconstruct as *slb, denotes 'order of years in the hexagenary cycle'. ${ }^{12}$ Kitan *syawqu 午专丈 'blue' and *tawlya 'hare, rabbit' 戈矢为 are well-known words. Middle Kitan *par 壬 ‘ten' is my revision of Róna-Tas's reconstruction (2016). Most of the other words in this line are well known in the Kitanological literature.

The word 圠叫 is a relatively high-frequency expression occurring across many Kitan Assembled Script texts (e.g. XHu 29:35; Xing 1:13; Renyi 11:19; Dao 4:13; Zhong 50:13), also written 圠伄伏 (YPu 1:10; YJue 1:25, 34:40, 7:39, 31:53;

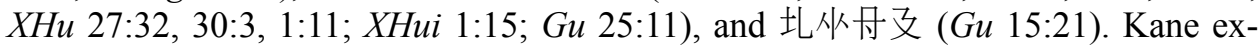
plains 圠伄出 in Xuan (K4:14) as 'first period of the month (朔)' (2009, p. 215, note $61)$. It is possible that the literal meaning of this word in Kitan is more idiomatic. It appears to be a verbal noun construction, composed of the verbal root *Gol- 圠佡 'see', corresponding to Chinese 睹 'see, observe' in the Langjun xingji 郎君行記 inscription (Lang K3:1, C2:11). ${ }^{13}$ Although no cognates to this Middle Kitan verb have been identified in Middle Mongol or the modern Mongolic daughter languages, the 4 element is a high-frequency functional morpheme, which I reconstruct as *-bəñ 'past or perfective verbal noun suffix', cognate to Middle Mongol $-b A i$ 'firsthand past tense suffix'. ${ }^{14}$ This suffix is also written 伏 $\sim$ 中支. The Middle Kitan translational equivalent to Chinese 朔 'first period of the month' thus probably literally means 'saw' or 'observed'. The Middle Kitan suffix *-bəñ is regularly used for forming relative clauses, and precedes the noun it modifies. Thus, the Kitan sequence 白壬山 圼为圠伄出包永令为为 probably literally means, in idiomatic Kitan, 'The third day, White Chicken, which saw/observed the eleventh month, Yellow Goat...' This sheds some light, however dim, on the idiomatic structure of Middle Kitan calendrical formulae. The actual meaning is still enigmatic. Future work on the word forms

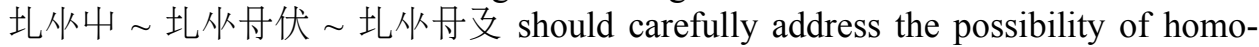
phones, and re-examine the previous proposals on the semantic values of this word as 'first, first-born', 'preface', and 'first day of the month', ${ }^{15}$ as well as the personal name(s) taking this phonological form.

The word 水 'white' has been semantically deciphered for some time, although its phonological value has remained a mystery. Recently, the Inner Mongolian scholar Jürkh ("Jiruhe' in Pinyin) proposed to read this grapheme as "su" or "siu" based on a variant reading (Oyuunch 2014). I revise this to ${ }^{*} \mathrm{su}$ 承 'white'. This word has no known cognates.

${ }^{12}$ See Kane $(2009$, p. $110, \S 3.147)$ for the semantic value of this word.

${ }^{13}$ In my article on the Langjun xingji 郎君行記 inscription, this character is erroneously given as “賭” ('gamble') in the retyped Chinese sentence, but it appears correctly as “睹” ('see, observe') in my commentary (Shimunek 2014, p. 102). Oyuunch and Janhunen (2010, p. 53) treat the Kitan word 圠你丹伏 as 'preface' < 'first', which they analyse as based on a root 圠你 'to begin'. Although they are correct that this word is formed from a root in 圠敒, their proposal on the semantic value of the root is unlikely, given the known Kitan verb 'see' in the Langjun xingji 郎 君行記 inscription.

${ }^{14}$ See Brosig (2014) on the value of this suffix in Middle Mongol and Shimunek (2017, pp. $287,295,322-323$ ) on the Kitan-Mongol correspondence.

${ }^{15}$ Osada Natsuki proposed these semantic values for the word (Kane 2009, p. 25). 


\section{[K5:1-8]}

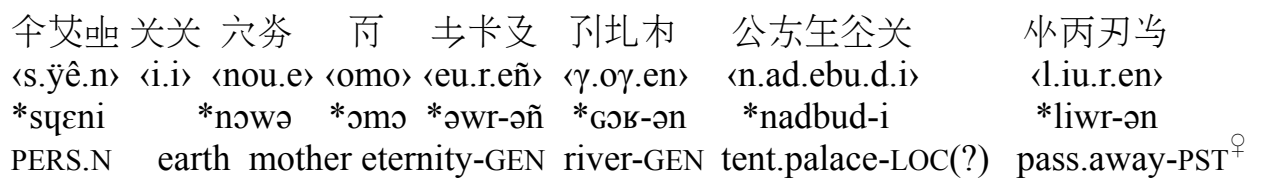

'Xuanyi Earth Mother passed away around/near her tent palace along the Eternal River (i.e. Changqing River).'

\section{[C4:1-10]}

\section{先稳德皇后崩于長慶川}

'The late Empress Yide [i.e. Empress Xuanyi] died at Changqing River. ${ }^{16}$

The Kitan and Chinese lines above closely correspond to each other. Most of the words in the Kitan line are well-known, deciphered words, with the exception of

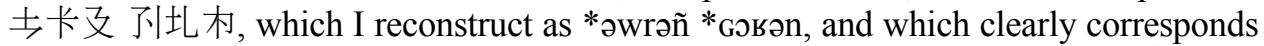
to 長慶川 Changqing River in the Chinese text. The word *nadbud 公东主爷 is known from other texts to denote the mobile tent palace, or ordo, of Kitan nobility, i.e. the nabo (Kane 2009 , p. 56, $\$ 2.176$, p. 92, p. 107, §3.130). Oyuunch $(2007$, p. 72 ) proposes that the 大 element appended to this word form might be a low-frequency locative case suffix, and identifies another attestation of this grapheme with a locative meaning in the Yelü Gui inscription, although he states that the specific grammatical function of this grapheme in these instances requires additional consideration. Although the specific meaning of the 大 element is unresolved, the Kitan text clearly specifies that Empress Xuanyi died at her ordo along the Changqing River. The *-ən 杭element is a genitive-attributive suffix, well attested in this form throughout many other

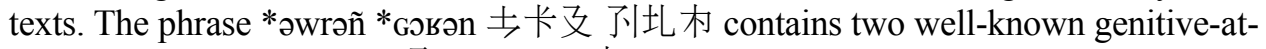
tributive suffixes, i.e. *-əñ 及 and *-ən 杭 and thus must be composed of NOUN+GEN NOUN+GEN. This construction is the Kitan equivalent to the hydronym 長慶川 'Changqing River', which literally means 'Eternal Blessings River' in Chinese. The noun * ${ }_{\text {Gว }}$ 了小圠 corresponds to Chinese 'river (川)' and is cognate to Middle Mongol qoroqan 'rivulet, brook'. ${ }^{17}$ Middle Kitan *awr 米 'eternal' corresponds to Chinese 長慶 'eternal blessings', and is cognate to Middle Mongol e'üri e'üre, glossed in the Secret History of the Mongols as 'a long time, for a long time; forever'. ${ }^{18}$ This Middle Mongol word is the root of later Written Mongol egüride > Khalkha üürd [u:rt] 'forever, always, eternally'. The Middle Kitan form is inflected with *-əñ 及 'genitive-attributive suffix'. Compare Written Mongol egüride-yin 'everlasting, eter-

\footnotetext{
${ }^{16}$ My translation of this line of the Chinese text is a revision of Kane (2009, p. 223).

${ }^{17}$ See Shimunek $(2017$, pp. 340-341, 426) for a detailed etymology and for my revised reading of the grapheme 卡.

${ }^{18}$ See Shimunek (2017, pp. 340-341) for a detailed etymology.
} 
nal' (Khalkha üürdiin ['u.rtin] 'id.') and Middle Mongol e'üri urtu, glossed as 'a long time, eternally' $(H Y Y Y)$. The Kitan name of this river thus appears to literally mean 'Eternal River', and partially corresponds semantically to the literal meaning of its Chinese name.

Chinggeltei et al. (1985) suggested that the word 水圠 denotes 'crow' or 'bird'. This proposal is based on a passage in the Xuanyi inscription which they suggested corresponds to the Chinese phrase 金烏西下, 玉兔東昇 'the gold crow sets in the west, the jade hare rises in the east' (cf. Chinggeltei 2002, p. 41, §76; Kane 2009); however, this phrase does not appear in the Chinese text of the Xuanyi inscription, and in the relevant passage in which this word occurs in the Kitan text, the wellknown Kitan graphemes for 'west' and 'east' make no appearance. In fact, little of this passage has been deciphered, aside from the word 'jade hare', the word for 'golden' or 'yellow', the high-frequency negative marker *gi, and two converb suffixes, *-i and *-Awr (or segments homophonous to these converb suffixes):

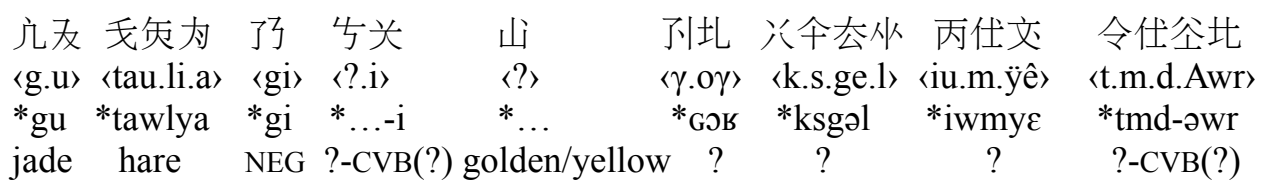

'The jade hare did not... and the golden/yellow ... ... and then...' (Xuan 29:9-17).

Although the phrase *gu *tawlya in this passage probably does mean 'jade hare', and despite the widespread acceptance of Chinggeltei et al.'s proposal, the specific meaning of $\}$ 小圠 in this particular passage is unclear, and it is unlikely that this Kitan passage corresponds to the Chinese phrase proposed by Chinggeltei et al. (1985).

The word 页圠 is attested in a few other texts, e.g. in the Xiao Dilu inscription, in the sequence 主了圠及 (XDi 7:22-23), which is a genitive case form composed

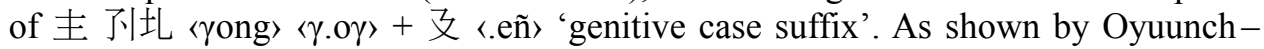
Janhunen $(2010$, p. 73$)$, this 主, which I transcribe as 〈yong〉 and read as *Goy, is a transcription of a Chinese syllable read huang in Modern Standard Chinese. This

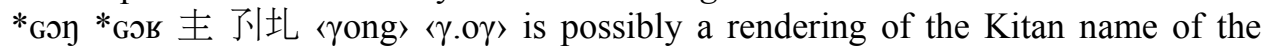
㣴水 Huang River, a major tributary of the Liao River, near the Kitan homeland. The sequence ${ }^{*}$ Goy * ${ }_{\text {Gor }}$ 主 小圠 also appears in the Yelü Jue muzhiming 耶律玦墓誌銘 inscription (YJue 21:44-45). Another occurrence of the grapheme sequence 了小圠 is in the Yelü Xiangwen muzhi 耶律詳稳墓誌 inscription (YXiang 46:3), although the meaning is not clear.

Despite the ambiguity of these attestations, I believe I have established the meaning of 了小圠 as 'river' based on the very straightforward correspondence with the Chinese river name Changqing, as discussed above. I have found no unequivocal evidence for the putative 'crow' 'bird' value of this grapheme sequence, despite its widespread acceptance in the Kitanological literature, although we should not rule out the possibility of homophonous words rendered by the same sequence of graphemes as 了圠 'river'. 
[K5:9-17]

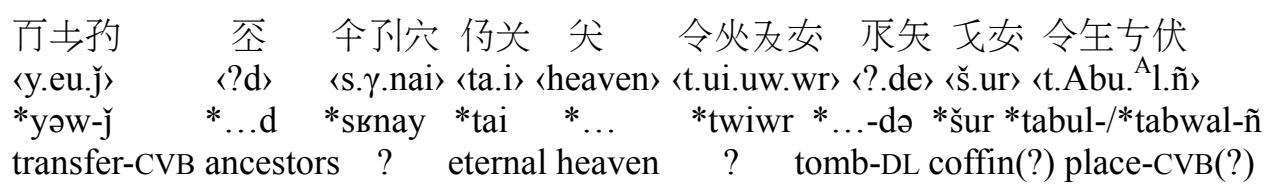

'[She was] transferred, and [they] placed [her] coffin(?) in the Eternal Heaven ... Tomb [of the] Ancestors.'

\section{[C4:11-16]}

\section{旋附殯于 祖陵}

'She was buried with her ancestors at Zuling., 19

The Kitan sentence appears to be richer in detail than the corresponding Chinese sentence. The verb *yəw- 百土 'be transferred' is cognate to Middle Mongol yabu' go', and * $*_{-\mathrm{j}}$ 㢩 'converb suffix' (probably 'perfective converb suffix') is cognate to Middle Mongol $-J U$ 'perfective converb suffix' ${ }^{20}$ Since the Chinese text mentions

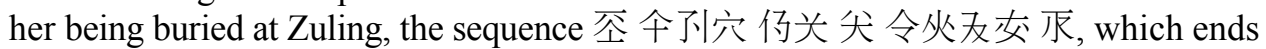
with the dative-locative case suffix 矢, must correspond to Chinese 祖陵 Zuling, although the Kitan sequence includes several words of unknown meaning. The first word in this sequence, 空, is a contraction of - 'north, upper, above', a word of unknown phonological value, and *-d 众 〈.d〉 'plural suffix', and has been semantically deciphered as denoting 'upper ones, superior ones' or 'ancestors' (Kane 2009, p. 36, $\$ 2.009$ ), but aside from the final $*-d$, the phonological value of this word is unclear. In Chinese, Zuling 祖陵 means 'ancestral tomb mounds', composed of 祖 $z u$ 'ancestor' and 陵 ling 'mound, tomb-mound'. It is thus likely that 空 here denotes 'ancestors' or 'ancestral'.

The word *ssnay 羊到穴〈s. $\gamma$.nai〉 is read by Chinggeltei et al. (1985) and Oyuunch (2007, p. 365) as 个小岀〈s. $\gamma . \ddot{\text { y }}$, but the grapheme in the published rubbing of the original text clearly has 穴 〈nai〉 and not 岀 〈ü. Chinggeltei (2002) and Kane (2009) correctly read this grapheme sequence as 企了穴. This word appears to be a hapax legomenon, and its semantic value is unknown.

The word *tai 㐷兴 is attested elsewhere, and has been deciphered as 'eternal' (Kane 2009, p. 216, note 62).

The word 矢 is known to mean 'heaven', although the phonological value is unknown.

${ }^{19}$ The translation of the Chinese text is from Kane (2009, p. 223).

${ }^{20}$ As shown by Brosig $(2014$, pp. 10, 29, 35) in his careful study of Middle Mongol tense and aspect based on the Secret History, Middle Mongol -JU is a perfective converb suffix, unlike its Modern Khalkha reflex $-ж[\mathrm{t}] \sim \sim-ч\left[\mathrm{t}^{\mathrm{h}}\right]$, which is an imperfective converb suffix. 
The word *twiwr 令众友交〈t.ui.uw.wr〉 is attested only one other time in the Kitan Assembled Script texts which were available to me at the time of writing this paper, in the form *twiwr-ər 令众友交炎〈t.ui.uw.wr.er〉, in which *twiwr 令众友交 〈t.ui.uw.wr〉 seems to be a noun of unknown semantic value, with *-ər 炎 〈.er〉 'accusative-instrumental-comitative suffix'. Not much more can be said, although the phonological form of this word is quite interesting, and seems to provide evidence of a $*$ tw sequence. Consonant $+/ \mathrm{w} /$ glide sequences are also attested for the related Serbi language of the Tuyuhun or 'Azha (cf. Shimunek 2017, pp. 183, 184, 193).

The word 瓜 denotes 'tomb' (Kane 2009, p. 36, §2.006; Oyuunch-Janhunen 2010, p. 116).

The word form *šur 交 〈š.ur〉 probably denotes 'coffin'. This meaning is evident in the the Xiao Huilian muzhiming 蕭回璉墓誌銘 inscription (XHui 12:27-32), the Daozong huangdi aice 道宗皇帝哀冊 inscription (Dao 5:29-30), and in the Song Wei guofei muzhiming 宋魏國妃墓誌銘 inscription (Song 6:1-7). ${ }^{21}$ Middle Kitan *u regularly corresponds to both Middle Mongol $\ddot{o}$ and $\ddot{u}$, and Middle Kitan *š corresponds to Middle Mongol $s$ (Shimunek 2017, p. 371). Middle Kitan *šur 'coffin' thus phonologically resembles modern Written Mongol sür 'splendor, grandeur, magnificence, majesty' and sör 'support, stand, trestle (e.g. for dried grass or for grapes)' $\sim$ sörü 'treillis ...; hangar couvert de chaume; s. modun juniper' (Kow. II 1435b), but a connection, if any, remains to be determined. Neither of these modern Written Mongol words are attested in Middle Mongol sources.

The word form 令主方伏〈t.Abu.Al.ñ〉 is probably a verb cognate to Written Mongol talbi- 'to place, set down' with *-ñ 伏 〈.ñ as an imperfective converb or past tense or perfective verbal noun. Since the verb stem 令主方 〈t.Abu.Al.〉 'place, set down' appears elsewhere with the causative-passive suffix *-ва- clearly indicating [-ATR] vowel harmony, this verbal root should probably be read *tabul- or *tabwal-, suggesting that the grapheme 年 denotes $\langle\mathrm{ebu}\rangle \sim\langle\mathrm{abu}\rangle \sim\langle\mathrm{bu}\rangle$ depending on phonological context. ${ }^{22}$

The specific semantic value of the verbal suffix *-ñ 伏〈.ñ $\sim *^{*}$-əñ 及 〈.eñ is not clear. It appears appended to several well attested verbs, e.g. *kuyr- 'arrive' in the form *kuyr-əñ 火众化及 〈k.ui.ir.eñ〉 (XHui 24:1), *tgə- 'die' in the form 令去及 〈t.ge.eñ〉 (XHu 15:35), *man- 'hunt' as 不出及 〈m.an.eñ〉 (YJue 41:14, 6:35; YPu 19:2, 6:18; XHui 12:25), *...- 'manage' as 㞋伏 «?.ñ (YJue 11:16), *oju- 'close (e.g.

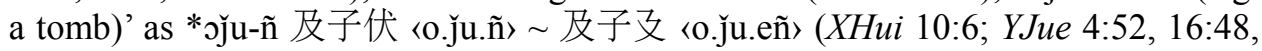
3:14; YPu 2:29), and numerous other semantically undeciphered verbs. Superficially, this suffix resembles, and is possibly cognate to, Middle Mongol $-n$ 'imperfective converb suffix' ${ }^{23}$ In some other instances this same ${ }^{*}$-ñ $\sim{ }^{*}$-əñ suffix, or a homophonous suffix, appears to indicate a finite past or perfective verbal noun. More work is neces-

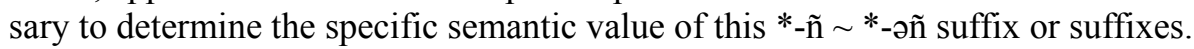

${ }^{21}$ Liu et al. (2009, p. 269) gloss 文 here as 'temporarily (權)' and 令生方关 as 'place a coffin in a temporary shelter pending burial (厝)'.

${ }^{22} \mathrm{Cf}$. Oyuunch and Janhunen's proposal to read this grapheme as 〈ebu (Oyuunch-Janhunen 2010, p. 154).

${ }^{23}$ As demonstrated by Brosig (2014), Middle Mongol $-n$ is a 'imperfective converb suffix'. 


\section{[K5:18-K6:4]}

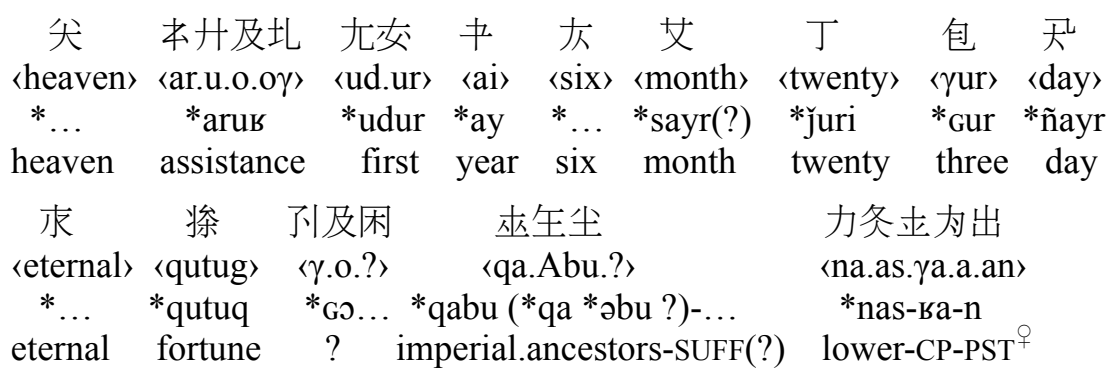

'In the first year of the Heavenly Assistance reign period, in the sixth month, on the twenty-third day, she was caused to be lowered among [her] imperial ancestors in the Eternal Fortune Tomb.

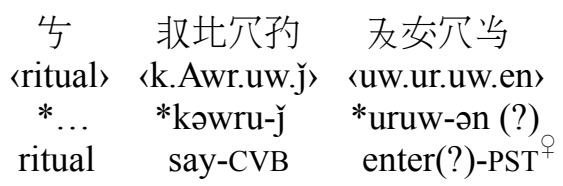

'Rituals were said, and [her body] entered [the tomb].'

\section{[C4:17-C6:7]}

\section{即以乾統元年歲次辛巳六月庚寅朔二十三日壬子將遷座於永福陵禮也}

'In the first year of the Qiantong period, the year was xinsi, the sixth month, gengyin, the new moon, on the twenty-third day, renzi, she was reburied in the Yongfu Tomb with the appropriate rituals.'

The reign period 尖 井及圠 'Heavenly Assistance' is composed of 尖 'heaven' and *aru-в 丸井及圠, from *aru- 'assist' with *-в 'deverbal noun suffix'. ${ }^{24}$

Róna-Tas (2016) reads the grapheme 丁 'twenty' as *jüri, which I revise to *juri 'twenty'.

The grapheme 生 probably renders a suffix, the precise semantic and phonological value of which remains to be determined.

The Kitan verb *nassa- 力冬关 corresponds to 遷座 'be reburied' in the Chinese text, and is probably cognate to modern Written Mongol namusqa- 'to lower, to cause to be lowered', the causative of the verb namus- 'to be low'. Although this word is not attested in Middle Mongol, its semantics and phonology match the Kitan verb well.

\footnotetext{
${ }^{24}$ See Shimunek (2017, pp. 421-422). See Kane's (2009) treatment of Kitan reign period names.
} 
The root and converb suffix of the word *kəwruw- 取比分㢩 are probably cognate to Written Mongol kemegdejü ${ }^{25}$ although there may be a suffix *-ruw- or *-uw- (or a sequence of affixes) of unknown semantic value.

This Kitan sequence may mean something like 'She entered [the tomb] with the rituals being said'. The last word in this section, *uwuruw-ən 友交分与, is a verb with the feminine past verbal noun suffix *-ən 当, suggesting that the subject of the verb is feminine - it must be Empress Xuanyi. One may entertain a possible cognate in Written Mongol oro- 'enter', although this poses phonological problems. The word *uwuruw- brings up the interesting question of rounded vowels and their orthographic representation in Kitan Assembled Script. This question remains to be addressed by Kitan scholarship. Many questions remain in the decipherment and linguistic reconstruction of this and many other Kitan texts.

\section{Middle Kitan-English Glossary}

\section{Semantically and Phonologically Deciphered Grammatical Morphemes}

*-an 出 'feminine past tense verbal noun suffix'.

*-Awr t 北 ‘.Awr? ' 'converb suffix (perfective?)'.

*-bəñ 廿 «.beñ 'past or perfective verbal noun suffix'.

*-da 矢 <.de〉 'dative-locative suffix' < CSM.

*-on 朴 〈.en〉 'genitive-attributive suffix allomorph' $<$ CSM.

*-ən 尚 〈.en〉 'feminine past tense verbal noun suffix' < CSM.

*-əñ 及 <.eñ ' 'genitive-attributive suffix' $<$ CSM.

*-əñ 及 <.eñ 'verbal suffix' (converb or past tense?).

$*_{-i}$ 大 $<$.i ' 'genitive-attributive suffix allomorph' $<$ CSM.

$*_{-i}$ 大 $<$.i ' 'lexicalised locative suffix (?)'.

$*_{-\mathrm{j}}$ 㢩 $\langle. \mathrm{j}\rangle$ 'converb suffix' $<$ CSM.

*-n 公 〈.n〉 'genitive-attributive suffix allomorph' < CSM.

*-ñ 伏 〈.ñ 'verbal suffix' (converb or past tense?).

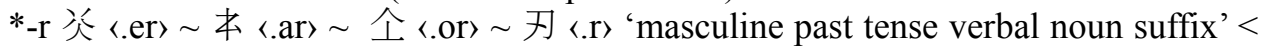
CSM.

*-un '父 ‘.un〉 'genitive-attributive suffix' $<$ CSM.

\section{Semantically and Phonologically Deciphered Words and Phrases}

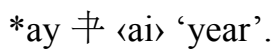

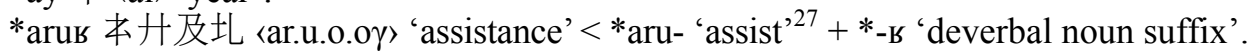

${ }^{25}$ See Oyuunch - Janhunen (2010, p. 69) for a similar proposal.

${ }^{26}$ See Shimunek (2017, pp. 422-423) for the reading of this grapheme.

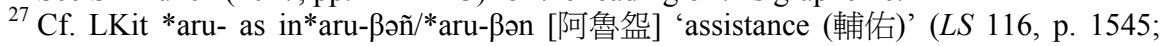
Shimunek, 2017, p. 422). 
*čaywun 机尔 圭父〈č.ai〉〈w.un〉 'text' $\leftarrow$ OMan. 冊文 'id.'.

*čgən 木几村〈č.g.en〉 'left' < CSM.

*owr 去米 〈eu.r〉 'eternal, long-lasting (長)' < CSM > PMgl > MMgl e'üri e'üre 'eternal'.

*cma 圣为 〈êm.a〉 'goat' < CSM > PMgl > MMgl ima'a-n 'goat'.

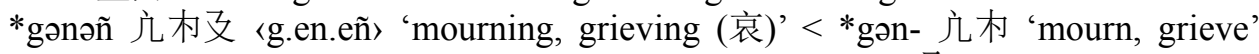
(cognate to WMgl yuni- 'be sad, melancholy'?) + *-əñ 及 'verbal suffix' (converb or past tense?).

*gemgyaw 几圼 几号 〈g.êm〉〈g.iau〉 'acting (of an official position)' $\leftarrow$ OMan. 檢校.

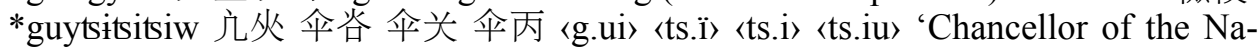
tional University’ $\leftarrow$ OMan. 國子祭酒.

*aol- 圠伄 〈 yo.1.> 'see, observe'.

* 'diminutive suffix').

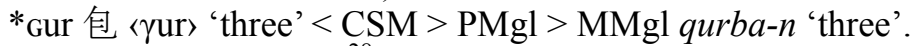

*juri 丁 〈juri〉 'twenty'. 28

*kəm 取金 $\langle\mathrm{k} . \mathrm{em}$ ' 'edict' < CSM > PMgl > MMgl kem 'limit'.

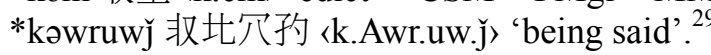

*ku 几 〈ku> 'person' < CSM > PMgl > MMgl gü' ̈̈ 'person'.

*liwr- 伄丙刃 〈l.iu.r.〉 'pass away (of an emperor or empress) (崩)'.

*mas 乇 〈mas〉 'one'.

*nadbud 公东主坌 〈n.ad. 'bu.d〉 'moving tent palace'.

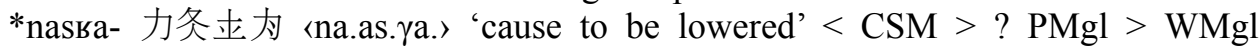
namusqa- 'to lower, cause to be lowered'.

*nowə 穴炎 〈nou.e〉 'earth'< ? CSM > PMgl > MMgl noqo'an 'green'.

*ñayr 天 〈ñayr? ' 'day'< CSM > PMgl > MMgl nara-n 'sun'.

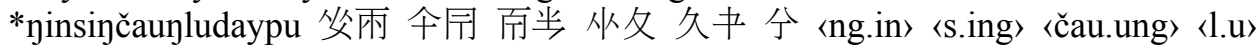
〈da.ai〉 〈pu〉 'Grand Master of Imperial Entertainments' $\leftarrow$ OMan. 銀青崇祿大 夫.

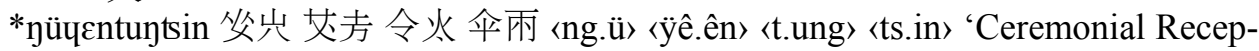
tionist' $\leftarrow$ OMan. 御院通進.

*oms 百 〈omo〉 'mother' < CSM > PMgl > MMgl eme 'woman, female'.

* par 允 〈par〉 'ten' $30<\mathrm{CSM}>\mathrm{PMgl}>\mathrm{MMgl}$ harba-n 'ten'.

*puwku 出友几 spu.uw.ku> 'official' $\leftarrow$ OMan. 僕 'servant' + MKit *ku 'person' $(<\mathrm{CSM})$.

*qa *əbu / *qabu (?) 來年 qa.Abu〉 'ancestors', a compound composed of *qa 來 〈qa〉 'emperor' (<CSM) and *abu 年 〈ebu〉 ${ }^{31}$ 'forefather, old man' (<CSM).

*quru 王尒 〈qur.u〉 'controller'.

${ }^{28}$ This is my revision of Róna-Tas (2016).

${ }^{29}$ See Oyuunch - Janhunen (2010) for a similar proposal.

${ }^{30}$ This is my revision of Róna-Tas (2016).

${ }^{31}$ Oyuunch and Janhunen (2010, p. 154) read the grapheme 生 as 〈ebu〉. 
*qutuq 松 'good fortune, $32<$ CSM.

*sayr 文 〈sayr?' ‘month'< CSM.

$*_{\text {slb }}$ 个夾母 〈s.l.b〉 'order of years in the hexagenary cycle'. 33

*su 承 〈su〉'white'. 34

*syawqu 午专丈〈s.iau.qu〉'blue'.

*šur 文交〈š.ur〉 'coffin'.

*tai 仍关〈ta.i〉 'eternal'.

*taqa 令为为 〈t.aq.a〉 'hen' < CSM.

*tawlya 戈矢为 〈tau.li.a 'hare, rabbit' < CSM > PMgl > MMgl taulai 'id.'

*tabul-/*tabwal- 令玍与 〈t. ${ }^{\mathrm{A}}$ bu. ${ }^{\mathrm{A}}$ l.〉 'place, set down'. Cognate to WMgl talbi- 'place, set down'.

*tiwr 令丙刃〈t.iu.r〉 'gathering' < *tiw- 令丙 'gather' $(<\mathrm{CSM})+*_{-r}$ 刃 'past tense verbal noun suffix'.

*udur 九交 〈ud.ur〉 'first'.

*uru- 友交八 (uw.wr.uw.〉 'enter' (?). Possibly cognate to MMgl oro- 'enter'.

*uwr 及化 〈uw.ur〉'division'.

*uy 众 〈ui〉 'matter' < CSM « OChi. 爲 'do'. 35

*wugiwi 圭友 几㪳众关〈w.u〉〈g.i〉〈ui.i〉 'Commandant of Military Cavalry' OMan. 武騎尉.

*yəw- 开寺 (y.eu.) 'transfer'. Cognate to MMgl yabu- 'go'. < CSM > PMgl > MMgl yabu- 'go'.

\section{Phonologically (Fully or Partially) Deciphered Words or Morphemes of Uncertain} Semantic Value

*k...y- 公圣开 〈k.?.y.〉 'do (?)' < ? CSM > PMgl > MMgl ki- 'do'.

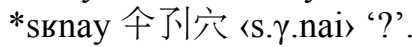

*twiwr 令众友交〈t.ui.uw.ur〉'?'.

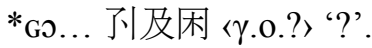

\section{Semantically Deciphered Words and Morphemes of Unknown (or Only Partially Known) Phonological Value}

*... 穴 $\langle$ ? $\rangle$ 'great'.

*... 生 $\langle$ ?〉 'suffix of unknown semantic value'.

*... 山 ??〉 'yellow, golden'.

${ }^{32}$ Kane (2009) first demonstrated that 柼 is a single grapheme and not a graphemic compound as was previously assumed.

${ }^{33}$ Kane $(2009$, p. 215 , note 61$)$.

${ }^{34}$ Deciphered by Jürkh (Oyuunch 2014).

${ }^{35}$ See Shimunek (2017, pp. 378, 408-409) for the etymology of this word in Serbi-Mongolic, Tungusic, and Sakha. 
*... 灰 $\langle ?\rangle$ 'six'.

*... 不 $\langle$ ? $\rangle$ 'tomb'.

*... $5\langle ?\rangle$ 'rites, rituals'.

*...-网 $\langle$. . 'compose'.

*...o- 雨 $\langle$ ?o.〉 'present to a superior, receive from a superior (奉)'.

*...- 㞋〈?.〉 'manage'

*...g 齊九 $\langle$.g〉' 'writing'.

*... 尖 $\langle$ ? ‘ 'heaven'.

*...d 空 〈?d〉 ‘ancestors, superiors, upper ones’ (cf. Kane 2009).

\section{Fully Undeciphered Words or Morphemes}

*...上旮 $\langle ? . ?>$.

\section{Onomastic Data}

* gu 九文 $\left\langle\mathrm{g} . \mathrm{u}^{\mathrm{w}}\right.$.u〉 ' $\mathrm{Gu}$ (personal name)'.

*sueni 全处吅 关火〈s.ÿê.n〉〈i.i〉 'Xuanyi'.

*yarud 百本友火 〈y.ar.uw.ud〉 'Yelü (Kitan imperial clan name)' < *yar 开本 'imperial clan name' $+*$-ud 友火 'plural suffix for people'. 36

\section{Sigla and Abbreviations}

\section{Sigla for Kitan Assembled Script Texts}

1101 Dao Daozong huangdi aice 道宗皇帝哀冊 (Chinggeltei 2002).

$1115 G u \quad G u$ Yelü shi mingshi 故耶律氏銘石 (Chinggeltei 2002).

1053 Jiao Yelü Zongjiao muzhiming 耶律宗教墓誌銘 (Liu et al. 2009).

1134 Lang Da Jin huangdi dutong jinglüe langjun xingji 大金皇弟都統經略郎君行記 (Chinggeltei 2002).

1076 Renyi Renyi huanghou aice 仁懿皇后哀冊 (Chinggeltei 2002).

1110 Song Song Wei guofei muzhiming 宋魏國妃墓誌銘 (Liu et al. 2009).

$1114 X D i \quad$ Xiao Dilu fushi muzhi 蕭敵魯副使墓誌 (Oyuunch-Janhunen 2010).

1091 XHu Xiao Hudujin muzhiming 蕭胡睹堇墓誌銘 (Oyuunch 2012).

1080 XHui Xiao Huilian muzhiming 蕭回璉墓誌銘 (Oyuunch 2012).

1055 Xing Xingzong huangdi aice 興宗皇帝哀冊 (Chinggeltei 2002).

$1105 X u \quad X u$ wang muzhi 許王墓誌 (Chinggeltei 2002).

1101 Xuan Xuanyi huanghou aice 宣懿皇后哀冊 (Chinggeltei 2002).

1071 YJue Yelü Jue muzhi 耶律玦墓誌銘 (Oyuunch-Janhunen 2010).

1105 YPu Yelü Pusuli muzhi beiming 耶律蒲速里墓誌碑銘 (Oyuunch 2012).

${ }^{36}$ See Shimunek (2017, pp. 67, 198) for this imperial clan name in Kitan Assembled Script and in Persian, Old Mandarin, and Middle Chinese transcription. 
1091 YXiang Yelü Xiangwen muzhiming 耶律詳稳墓誌 (Oyuunch-Janhunen 2010).

1150 Zhong Xiao Zhonggong muzhi 蕭仲恭墓誌 (Chinggeltei 2002).

\section{Sigla for Chinese Texts}

LS Tuotuo 脫脫 [Toqto'a]. Liao Shi 遼史. Peking, Zhonghua Shuju, 1974.

\section{Sigla for Middle Mongol Texts}

HYYY Hua-Yi yiyu 華夷譯語. 14th century (Kuribayashi 2003).

SHM Mongqol-un niuča to[b]ča'an (Secret History of the Mongols). 13th century (Kuribayashi 2009).

\section{General Abbreviations and Transcription Conventions}

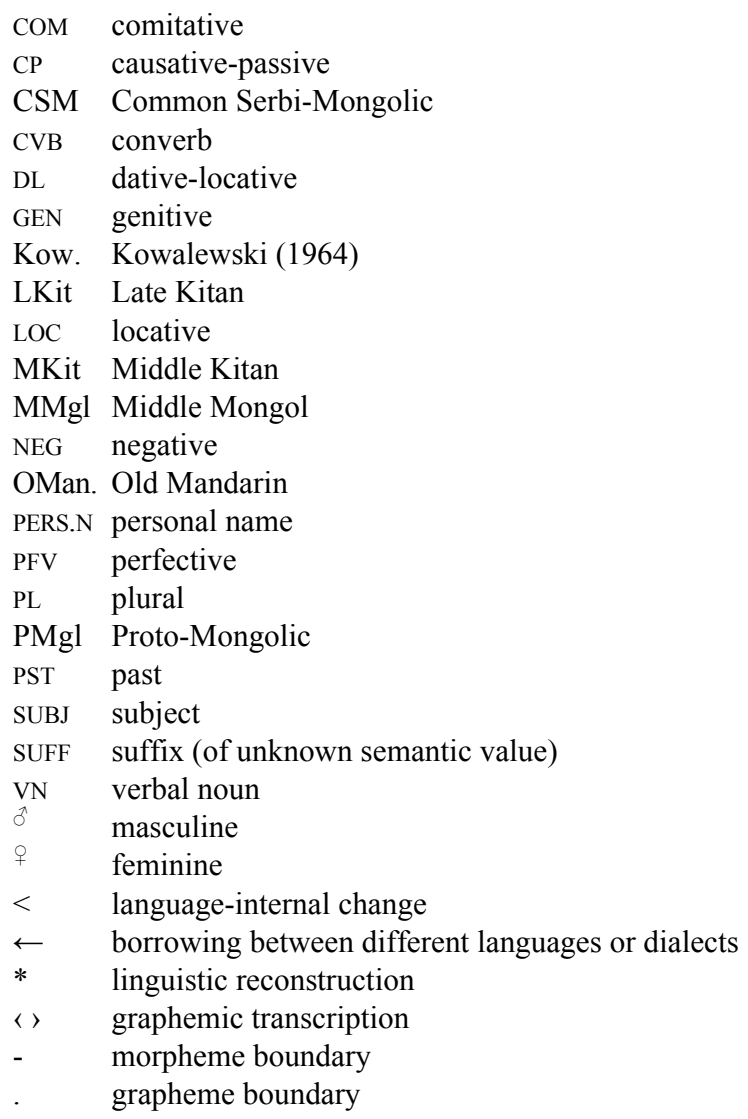




\section{References}

Batu = Ji Shi 即实 (2012): Mitian gengyun: Qidan xiaozi jiedu xu 谜田耕耘: 契丹小字解读续. Shenyang, Liaoning minzu chubanshe.

Brosig, Benjamin (2014): Aspect, Tense, and Evidentiality in Middle Mongol. Урало-алтайские исследования Vol. 2, No. 13, pp. 7-38.

Chinggeltei = Qinggeertai 清格爾泰 (2002): Qidan xiaozi shidu wenti 契丹小字釋読問題. Tokyo, ILCAA.

Chinggeltei et al. = Qinggeertai 清格爾泰 - Liu Fengzhu 刘凤泉-Chen Naixiong 陈乃雄 $-Y u$ Baolin 于宝林-Xing Fuli 邢复礼 (1985): Qidan xiaozi yanjiu 契丹小字研究. Peking, CASS.

Hucker, Charles O. (1985): A Dictionary of Official Titles in Imperial China. Taiwan Edition. Reprinted by Southern Materials Center, Inc., Taipei.

Kane, Daniel (2009): The Khitan Language and Script. Leiden, Brill (Handbuch der Orientalistik 19).

Kara, György (2005): Books of the Mongolian Nomads. Bloomington, Indiana University Press.

Kowalewski, Jozef Szczepan (1964): Dictionnaire mongol-russe-français. 3 vols. New York, Paragon Reprint Corp. Originally published in Kazan, Impr. de l'Universite, 1844-1849.

Kuribayashi Hitoshi 栗林均 (2003): Ka-i yakugo (kōshubon) Mongorugo zen tango, gobi sakuin 「華夷訳語」(甲種本) モンゴル語全単語・語尾索引. Sendai, CNEAS.

Kuribayashi Hitoshi 栗林均 (2009): “Genchō hishi” mongorugo kanji on'yaku, bōyaku kango tai$s h o ̄ g o i 「$ 元朝秘史」モンゴル語漢字音訳・傍訳漢語対照語彙. Sendai, CNEAS.

Liu Fengzhu (1999): Seventy Years of Kitan Small Script Studies. In: Janhunen, Juha-Rybatzki, Volker (eds): Writing in the Altaic World. Helsinki, The Finnish Oriental Society (Studia Orientalia 87), pp. 159-169.

Liu Fengzhu 劉鳳翥 (2014): Qidan wenzi yanjiu leibian 契丹文字研究類編. 4 vols. Peking, Zhonghua Shuju.

Liu et al. = Liu Fengzhu 劉鳳翥-Tang Cailan 唐彩蘭-Qinggele 青格勒 (Chinggel) (2009): Liao Shangjing diqu chutu de Liaodai beike huiji 遼上京地區出土的遼代碑刻彙集. Peking, Shehui kexue wenxian chubanshe.

Oyuunch = Wu Yingzhe 吳英喆 (2007): Qidanyu jingci yufa fanchou yanjiu 契丹语静词语法范 畴研究. Höhhot, Neimenggu daxue chubanshe.

Oyuunch $=\mathrm{Wu}$ Yingzhe 吳英喆 (2012): Kittan shōji shinhakken shiryō shakudoku mondai 契丹小 字新発見資料釈読問題. Tokyo, ILCAA.

Oyuunch = Wu Yingzhe 吳英喆 (2014): Guanyu ruogan Qidan yuanzi de duyin 矢于若干契丹 原字的读音. Altai Hakpo 알타이학보 Vol. 24, pp. 129-134.

Oyuunch-Janhunen = Wu Yingzhe-Janhunen, Juha (2010): New Materials on the Khitan Small Script: A Critical Edition of the Xiao Dilu and Yelü Xiangwen. Folkestone, Global Oriental (Languages of Asia 6).

Poppe = Поппе, Н. Н. (1938): Монгольский словарь Мукаддимат ал-Адаб. Часть I-II. Москва, Издательство Академии Наук (Труды Института Востоковедения XIV).

Poppe, Nicholas (1954): Grammar of Written Mongolian. Wiesbaden, Harrassowitz Verlag.

Róna-Tas, András (2016): Khitan Studies I. The Graphs of the Khitan Small Script: 1. General Remarks, Dotted Graphs, Numerals. $A O H$ Vol. 69, No. 2, pp. 117-138.

Shimunek, Andrew (2011): Review of The Kitan Language and Script by Daniel Kane. AOH Vol. 64, No. 1, pp. 101-107.

Shimunek, Andrew (2014): A New Decipherment and Linguistic Reconstruction of the KhitanChinese Bilingual Inscription of 1134 A.D. $A O H$ Vol. 67, No. 1, pp. 97-118. 
Shimunek, Andrew (2017): Languages of Ancient Southern Mongolia and North China: A Historical-Comparative Study of the Serbi or Xianbei Branch of the Serbi-Mongolic Language Family, with an Analysis of Northeastern Frontier Chinese and Old Tibetan Phonology. Wiesbaden, Harrassowitz Verlag (Tunguso-Sibirica 40).

Tang, John (2011): On the Terms for 'Goat' Recorded in Khitan and Jurchen Scripts. Altai Hakpo 알타이학보 Vol. 21, pp. 191-203.

Toqto'a = Tuotuo 脫脫 (1974): Liao Shi 遼史. Peking, Zhonghua Shuju. 